\title{
Türkçe Mizah Basınında İlk Polemik: Terakki ile Diyojen
}

\section{The First Polemic in the Turkish Humorous Press: Terakki and Diyojen}

\section{Gökhan DEMİRKOL*}

Öz: Türk Basın Tarihi'ne “polemik” kavramı ilk kez 1860 yılında Ceride-i Havadis ile Tercüman-ı Ahvâl gazeteleri arasında yaşanan tartışma ile girmiştir. İki gazetenin arasında yaşanan olayların temelinde mesleki rekabetin yer aldığı polemiğin bir benzeri de ilk Türkçe mizah dergileri Terakki ile Diyojen arasında yaşanmıştır. 1870 yılında Terakki gazetesinin mizah eki olarak yayınlanan Terakki Dergisi yayın hayatını tek Türkçe mizah dergisi olarak sürdürürken Diyojen Dergisi'nin Türkçe bir dergi yayınlaması Türkçe mizah dergileri arasında yaşanan ilk polemiğin çıkış sebebi olmuştur. Bu çalışma, Terakki ile Diyojen arasında yaklaşık bir yıl süren polemiği konu almaktadır. İki dergi arasında yaşanan polemik aynı zamanda dönemin mizah ve mizah dergiciliğinin durumuna ilişkin tespitler yapmaya yardımcı olacaktır. Bunun yanı sıra bu çalışmanın akademik anlamda az çalışılan Türk Mizah Dergiciliği hakkında da literatüre katkı sağlayacağı düşünülmektedir.

Anahtar sözcükler: Türk Basın Tarihi, Türkçe Mizah Dergileri, Polemik, Terakki, Diyojen

\begin{abstract}
The notion of "polemic" in Turkish press history was used for the first time when the discussion between Ceride-i Havadis and Tercüman-ı Ahvâl took place in 1860. The basic issue took place between two gazettes was about the polemic of occupational competition and a similar case took place between the first Turkish humorous magazines: Terakki and Diyojen. While the Terakki magazine, issued as a humorous supplement to the gazette Terakki in 1870, continued its press life as the first Turkish humorous magazine; the magazine of Diyojen's issue of the Turkish magazine, caused the first polemic between Turkish humor magazines. This study investigates a polemic held between Terakki and Diyojen which lasted for about a year. The polemic between these two magazines also helps in determining the cases of humor and humorous magazine publishing of that period. Additionally, it is thought that this study will also help in understanding the literary contributions made through Turkish humorous magazine publishing which has not been widely studied in the academic area.
\end{abstract}

Keywords: History of Turkish Press, Turkish Humorous Magazines, Polemic, Terakki, Diyojen

\section{Giriş}

“Polemik”, “(...) sert bir fikri mücadele”yi (Demir 2004, 185) içermesi anlamında ele alınd1ğında "rekabet" ve "iktidar kurma" ya da "mevcut iktidarı muhafaza etme" eylemleri üzerinden değerlendirilmesi gereken bir kavram olarak ortaya çıkmaktadır. Bu yaklaşım çerçevesinde polemikler, tarafların birbirleri üzerinde iktidar kurabileceği ya da mevcut iktidarlarını sürdürebilecekleri alanlar ve söylemler etrafında gerçekleşir. Bunun için kullanılan temel yöntem ise karşı tarafın olumsuzluklarını, aksayan yönlerini, eksikliklerini, kamuoyu tarafından bilenmeyen taraflarını gözler önüne sermek kısacası rakiplerinin "cemaziyelevvellerini” gün 1şığına çıkar-

\footnotetext{
* Yrd. Doç. Dr., Çankırı Karatekin Üniversitesi, Güzel Sanatlar Fakültesi, Sinema-TV Bölümü, Çankırı. gokhand06@yahoo.com
} 
maktır (Cemaziyelevvel, kamer takviminde bir ay adı olmakla birlikte bir kişinin kötü geçmişini bilmek anlamina da gelmektedir).

Türk Basın Tarihi'nde bilinen ilk polemik Ceride-i Havadis gazetesi ile Tercüman-ı Ahvâl gazetesi arasında yaşanmıştır. Bu polemiğin konusu ise Şinasi'nin "Şair Evlenmesi” isimli oyunudur. Güçlü bir yazı kadrosuyla (Tercüman-ı Ahvâl' in yazar kadrosunda Agâh Efendi, Şinâsi, Ahmet Vefik Paşa, Sarı Tevfik Bey, Mehmet Şerif Bey, Refik Bey, Hasan Suphi Efendi bulunmaktadır. İnuğur 2005, 188) yayın hayatına başlayan Tercüman-ı Ahvâl, yaklaşık yirmi yıldır tek başına faaliyet gösteren Ceride-i Havadis'e bir anda rakip olmuştur. Bu yeni gazete 2. say1sindan 5. sayısına kadar "Şair Evlenmesi" oyununu tefrika eder. Tefrika, okuyucunun ilgisini çekmiş ve gazetenin tirajını arttırmıştır. Türk Basın Tarihi'nde yayınlanan ilk tefrika olma özelliğine de sahip "Şair Evlenmesi" oyunu hakkında Ruznâme-i Ceride-i Havadis'in 29. sayısında “(...) kocakarllara mahsus mesel (...)” (Ruznâme-i Ceride-i Havadis, 25 Cemaziyelevvel 1277) tanımlaması yapılır (Söz konusu yazıda Avrupa'daki gazetelerin içerikleri hakkında bilgi verilirken Fransız gazetelerinin bir sayfa “(...) Tercüman-ı Ahvâl' in tefrikasında yazılan ebu-l laklaka oyunu gibi kocakarılara mahsus mesel (...)” gibi tefrika yayınladığı anlatılmaktadır). Bu tanımlamaya Tercüman-ı Ahvâl 10. sayısında İstanbul'da yayınlanan gazetelerin listesini çıkararak karşılık verir. 15 gazetenin isimleri, sıfatları ve sahiplerinin yer aldığ listede Ceride-i Havadis yarı resmi bir gazete ve sahibi de İngiliz olarak gösterilirken Tercüman-ı Ahvâl ise özel gazete ve sahibi de ehl-i İslam olarak tanımlanır. Listenin sonunda yer alan açıklamada ise Ceride-i Havadis için masrafı ve kârı sahibinin olmakla birlikte devletten de maaş aldığ yer alır (Tercüman-1 Ahvâl, 10 Cemaziyelahir 1277). Yayınladığı liste ile Tercüman-ı Ahvâl, Ceride-i Havadis'e iki noktada eleştiri getirmektedir. Bunlardan ilki devletten yardım alması, ikincisi ise gayrimüslim bir gazete sahibi olarak Müslüman bir gazete sahibine saldırmasıdır. $\mathrm{Bu}$ iki nokta aynı zamanda kendi sermayesiyle yayınlanan ve sahibi Müslüman olan tek gazete olması itibariyle Tercüman-ı Ahvâl'i tanımlayan unsurlardır.

İlk örnekleri 19. yüzyılın ikinci yarısında ortaya çıkan Türkçe mizah basını da polemik konusunda oldukça zengin bir alandır. Bu alanda ilk polemik ise mizah dergiciliği türünün Türkçe'deki ilk örnekleri olan Terakki ile Diyojen arasında yaşanmıştır.

Terakki, Filip Efendi ve Ali Raşid'in sahibi olduğu Terakki gazetesinin mizah eki olarak 12 Safer 1287 (14 Mayıs 1870) tarihinde yayın hayatına başlamış ilk Türkçe mizah dergisidir. Teodor Kasab'ın sahibi olduğu Diyojen ise Türk Basın Tarihi'nin ilk müstakil mizah dergisidir. 29 Şaban 1287 (24 Kasım 1870) tarihinde ilk Türkçe nüshasını yayınlayan Diyojen, Terakki ile birlikte Türk Mizah Dergiciliği’nin ilk adımlarını oluşturmaktadır.

Çalışmada Türkçe mizah dergiciliğinin ilk örnekleri olan Terakki ile Diyojen arasındaki polemik konu edinilmiştir. Her iki derginin birbirlerini hedef alan yazıları incelenerek polemiğe esas olan konular ve bu konuları ele alırken kullandıkları söylemin tespit edilmesi amaçlanmıştır. Bu amaç doğrultusunda Terakki'nin 33, Diyojen'in 13 sayısı incelenmiştir. İncelemede tekrara düşmemek için kronolojik bir yol izlenmiştir. Türkçe mizah dergilerinde yaşanan ilk polemiğin inceleme konusu olarak seçilmesi dönemin mizahçılarının birbirlerine ve de mizah dergiciliğine yaklaşımlarının ortaya konulması açısından önem arz etmekle birlikte Tanzimat Mizahı'na ilişkin literatüre de katkı sağlayacağı düşüncesinden kaynaklanmıştır.

\section{Terakki-Diyojen Karşı Karşıya}

Terakki ile Diyojen arasında yaşanan polemiği iki evrede ele almak mümkündür. Bu evrelerin ilki Diyojen'in Türkçe nüshasının yayınlanmasından önce yaşananlar, ikincisi ise Diyojen'in Türkçe nüshasının yayınlanmasından sonra yaşananlardır. İki dergi arasında yaşanan polemiğin 
birinci evresine ilişkin Diyojen'in Fransızca ve Rumca nüshalarının arşivlerde bulunmaması sebebiyle sağlıklı bir analiz yapmak imkânsızdır. Bununla birlikte iki dergi arasında yaşananları anlamlandırabilmek için bu evrede Terakki Dergisi'nde yer alan yazılara da bakmak gereklidir. Diyojen'e ilişkin Terakki'de yer alan ilk yazı 19 Safer 1287 (21 Mayıs 1870) tarihli 2 numaralı nüshada yer alır:

"Bir gazeteci (Diyojen)e sorar ki yeni bir gazete ihdas ettim, fakat müşterilerim azdır buna çare ne?

(Diyojen)

Tarizata başlamadın mi?

(Gazeteci)

Ben vicdan ve insaf sahibiyim.

(Diyojen)

Öyle ise halin fena gazeten ileri varmaz” (Terakki, 19 Safer 1287).

Yazıda açıkça Terakki, Diyojen'in meslek anlayışını ve de meslek ahlakını eleştirirken “tariz” noktasında da sınır tanımadığını belirtmekle birlikte bu sayede varlığını sürdürdüğünü ifade etmektedir. Terakki'nin neden böyle bir iddiada bulunduğu ya da Diyojen'in hangi yazısına karşılık böyle bir fikra yayınladığı tespit edilememektedir. Terakki'de yayınlanan ikinci yazı ise 5. sayıda Diyojen'den iktibas edilen bir muhaveredir:

Şirket-i Hayriye vapurlarından birinde Anadolu'dan yeni gelmiş adamın biletçiyle vuku bulan muhaveresini (Diyojen) gazetesi ber-vech-i âti yazıyor.

- Ulan biletçi bana bir bilet versene

- Nereye gideceksin

- Ne ki lazım (bu sirada biletçi gider)

- Amma adama çattık ha herif gitti ya hey ulan Çelebi Beylerbeyi'ne gideceğim gel bir bilet ver

- Altmus para vereceksin

- Yok otuz para

- Burada pazarlik olmaz

- Çok şey iyi kırk para vereyim uzatma da

- Altmış paradan aşağı olmaz

- Elli para da mi olmaz

- Hayır

- Canım tarla mı Ístanbul'da her şey alafranga olmuş peki altmış para olsun al şu mecidiyeyi boz (biletçi bir bilet on dokuz buçuk kuruş verir)

- Bir kuruş daha vereceksin

- Mecidiyeyi yirmi bire alırı

- Ne demek yirmi iki kuruştur asıl bunun pazarllğı olmaz Âdetimiz böyledir

- Öyle ise ver mecidiyemi ben bilet istemem

- Al

(Beylerbeyi iskelesine vusullerinde)

Iskele memuru-Hemşeri biletini ver

- Yok

- Git yazıcidan al

- Mecidiyeyi yirmi ikiye vereceğim

- Hayir yirmibiredir

- Öyle ise bilet kırk para 
(İskele memuru o aralık herifi itip kakar o dahi birkaç yumruk atıp parmaklıktan dışarı çıkar ve nihayet zabıta-i mahalliye merkezine giderler)

Zabıta memuru- Şirket-i Hayriye'nin adamını niçin dövdün

- Yoluma gitmekliğime ne diye çaparı olunur

- Niçin bilet parasını vermedin

- Benim gündüz akşama kadar çalışarak alnımın teri ile kazanıp yirmi ikiye almış olduğum mecidiyemi yirmi bire almak istiyor onun için

(Bu cevap üzerine merkez zabıta merkumu salıverir ve seyirciler el çırpar) (Terakki, 11 Rebiülevvel 1287).

Bu metinde Diyojen'e ilişkin açık bir eleştiri ya da saldırı bulunmamakla birlikte Terakki'nin bu muhavereyi neden yayınladığına dair bir bilgiye de dergi içeriğinde rastlanmamaktadır. Ancak Asır gazetesinin 7. sayısında yayınlanan bir mektup konuya açıklık getirmektedir:
“Beylerbeyi iskelesi bilet memuru Redif Bey tarafindan Diyojen'den -ki Beyoğlu'nda tab 'olunur Fransizca mashara bir gazetedir- Terakki Cuma günü çıkardığ Dalkavuk nüshasına Beylerbeyi iskelesinde bir Türk ile biletçi beyninde vuku' bulmuş diye bir muhavere nakletmiş. Böyle bir muhavere vuku bulsaydı veya tuhaf bir şey olsaydı sükût kabil idi. Hâlbuki esast yok ve gayet soğuk bir yalanı mahall-i memuriyetime azv ettiği için sahibine reddederim" (Özyıldırım 2014, 40).

Terakki'nin Diyojen'den aktardığı muhavere, Asır gazetesindeki bu mektup dikkate alındığında “tariz" noktasında Diyojen'in sınırlarını göstermek amacıyla yayınlanmış bir metin olarak kabul edilebilir. Söz konusu metine konu olan olayların gerçek dışılığı, mektubun yazarı olan Beylerbeyi iskelesi bilet memuru Redif Bey tarafindan dile getirilmekle birlikte aktarılan olaylar "soğuk bir yalan" olarak tanımlanmaktadır. Bu noktada Terakki amacına ulaşmış olmakla birlikte Redif Bey tarafından "dalkavuk nüshası" olarak tanımlanarak Diyojen'in "tariz”ine ortak edilmekten de kurtulamamıştır. Yukarıda da ifade edildiği gibi Diyojen'in bu süreçte verdiği tepkiyi bilemediğimiz için iki dergi arasında yaşanan polemik hakkında sadece varsayım ileri sürebilmekteyiz.

\section{Terakki’ye rakip olarak “Türkçe” Diyojen}

Terakki ile Diyojen arasında yaşanan polemiğin ikinci evresinin başlangıcını ise Diyojen'in yayın hayatını Fransızca ve Rumca devam ettirirken Türkçe bir nüsha çıkacağını ilan etmesi oluşturmaktadır. Türkçe nüshanın yayınlanması konusu Terakki'nin 1. sayısında ele alınır (Terakki gazetesinin eki olarak yayın hayatına başlayan Terakki mizah dergisi 13 sayı yayınlandıktan sonra gazetenin aldığı bir aylık kapatma cezası ile yayınına ara verir. Yaklaşık iki ay sonra tekrar yayınlanmaya başlayan Terakki sıra numarasını "1" den başlatır. Demirkol 2016, 141-160):

“(Diyojen) nam eğlence gazetesi haftada bir defa bir nüshada Türkçe neşr edeceğini geçenki nüshalarından birinde ama hangisinde olduğunu bilemiyorum (belki kendisine sorulsa o da bilmez) yazmış ve ibtidâ-yı zuhûrî levhasının tekmil olduğu zamanda olacağını yani baş açık meydana çıkamayacağını ilave etmiş idi. Henüz zuhur etmediğinden daha başına münasib bir şeyi uyduramadığı anlaşılır. Diyapazon işittiğimize göre hiçbir şeyi kaydında değil laubali meşreb bir feylosof kelbi mezhep olduğundan ve hatta daima baş açık gezmeye alıştı̆̆ından şimdi zavallı adamı başına tuhaflık olsun deyu bir külah giydirip zor ile nezleye uğratacaklarını ma 'at-te'essüf cümleye beyan ederiz. Vah vah vah"

(Terakki, 10 Şaban 1287). 
Diyojen, Fransızca ve Rumca nüshalarının birinde duyurduğu Türkçe nüsha için Terakki’nin yazısından anlaşıldığı üzere bir takım hazırlıklar içerisindendir. Bu hazırlıkların en önemlisi de derginin serlevhasıdır. Terakki, Diyojen'in ilan etmesine karşın Türkçe nüshanın çık(a)mamasını serlevhasının gecikmesiyle açıklarken bu gecikmeyi dergiye isim babalığı yapan Kinik felsefenin önemli isimlerinden Sinoplu Diogenes (Diyojen) üzerinden ele almaktadır. Sokratik geleneğin özgün kollarından birisi olan Kinik okul, Antisthenes tarafından kurulmuş olmasına karşın bu felsefe ekolünün en popüler ismi Sinoplu Diyojen (Diogenes) dir. Kinik okul genel olarak "zamanin hâkim ideolojilerini geçersizleştirmeyi" amaçlayan hicivci ve aforizmatik bir söylem içerisinde, bütün yerleşik toplumsal tabulara meydan okuyan, insanın ihtiyaçlarını, kısmen fiziki alıştırma ve talim (askesis) yoluyla erişilecek bir kendine yetme (autarkeia) idealinin bir parçası olarak en aza indirgemeye, buna mukabil sözünü hiçbir şekilde sakınmama anlamında konuşma hürriyetini (parrhesia) ve eylem özgürlüğünü (eleutheria) olabildiğince artırmaya dayanan bir ahlak anlayışı geliştirmiştir (Cevizci 2014, 172-173). Bu noktada Diyojen, teori ile pratik birlikteliğini hayata geçirmesi açısından önemli bir figürdür. Diyojen'e göre insanın yapması gereken şey kelimenin mecazi anlamında değil gerçek anlamda hayvan gibi yaşamas1, "köpeksi” bir hayat sürmesidir (Arslan 2010, 164). Terakki, temel söylemini Diyojen'in felsefesi ve yaşam şekli üzerine kurmaktadır ki bu durumu da “(...) hatta daima baş açık gezmeye alıştığından (...)" ifadesi ile okuyucuya aktarmaktadır. Terakki'nin 3. sayısında yayınlanan, "yanlışlıkla" gazeteye gelmiş olan mektup bu hayat tarzıyla ilişkili Diyojen'e ilişkin yeni bir tanımlama daha ortaya koymaktadır:

"Vah (Diyojen) vah....

(Diyojenin) muharrirlerinden birine gönderdiği bir mektuptur ki yanlışlıkla matbaamıza gelerek açılmış bulunduğundan (Terakki)'nin eğlence olarak çıkarılan iş bu nüshasına derc olundu.

Mektup

Dün değil evvelki gece bürudet-i havanin bedenime şiddet-i tesirinden sabah vakti güneş tulû' eder etmez bir miktar tadil-i mizaç için meskenim olan fiçıdan huruç etmiş idim.

Malum a. Reisi bulunduğum mezheb-i kelbi ki dünyada me'kûlat ve melbûsat ve sair tecemmülâtca köpek gibi yaşamaktır. İşte ben dahi her türlü melabisden sade ve azade yani çırll çıplak olduğum halde bilmem galiba biraz telaş ile firlamışım. Bir de şu halimi görenler hikmetime degil cennetime haml ederek beni kaptlklarl gibi gayet muntazam kargir bir ebniyeye götürdüler. Ben ise evvela bu mahalli eski Roma veya Atina darülfünunu zan edip kendimi oraya muallim-i evvel tayin olundum gayesiyle hemen mevcud bulunanları başıma toplayı neşr-i malumata ve arada ber-mu'tâd birazda nakl-i mudhikata başlamış isem de meğer mahal-i mezkûrda ol kadar feylosof üstad ve hekim garâyib icad mevcud imiş ki sözlerim indlerinde saçma. Ve artık bize burayı birakıp kaçma kaldı. Şu kadar ki Türkçeyi henüz paralamaya başladığımdan yalnız iş bu mahallin ismini öğrenerek hülâsamın çaresini bulmak için bir hayli uğraşıp (tımarhane) olduğunu anladım işte şimdi eski hikmet u fünûna bezl ttmarhanede neşr u talim-i cünûn ile meşgul bulunduğumdan ve hala neşr ettiğimiz gazete için burada deliyi güldürecek kadar kuvve-i kalemiyeye malik iki zâtı dahi refâkatinize ayarttığımdan sebilimizin sür'at-ı tahliyesine himmetinizi ümid ederim... (Diyojen)

(Terakki) 
Artık bundan böyle Diyojenden dinleyecekleri saçmaları şimdiden abonelerine tebrik ederiz" (Terakki, 25 Şaban 1287).

Kinik felsefenin en popüler ismi olan Diyojen'in mensubu olduğu felsefe okulunun ismi üzerinden Terakki'nin yaptığ 1 "mezheb-i kelbi” (“Kelbi” kelimesi Kinik felsefe için kullanılmakla birlikte "köpeksi, köpeğe ait" anlamına da gelmektedir) tanımlaması ve savunduğu hayat tarzını "dünyada me'kûlat ve melbûsat ve sair tecemmülâtca köpek gibi yaşamak" şeklinde ifade etmesine ek olarak yanlışlıkla Terakki matbaasına gelen bu mektubun "tımarhane"den gönderildiğini belirtilerek Diyojen'e atfedilen “deli” tanımlaması Terakki’nin Diyojen’in Türkçe nüshasına ilişkin eleştirilerinin temel hareket noktasını oluşturmaktadır. Bu noktadan hareketle denilebilir ki Terakki tarafından Diyojen'e ilişkin yapılan tanımlamalar asli olarak derginin içeriği üzerinde odaklanmaktadır. Bir fiçıda çırılçıplak bir şekilde "köpek gibi” yaşayan ve akli melekelerini yitirmiş bu meczubun tımarhaneden bulduğu iki zat ile yayınladığı derginin abonelerine söylenecek tek şey “Diyojenden dinleyecekleri saçmalar”a hazırlıklı olmalarıdır.

Polemiğin konusu olan Diyojen'in Türkçe nüshası, 29 Şaban 1287 (24 Kasım 1870) tarihinde yayınlanır. Nüshanın serlevhasında fiçısında oturan Diyojen ve onun karşısında ayakta ise Büyük İskender durmaktadır. Serlevhadaki resmin altında da Diyojen'in İskender'e söylediği meşhur söz yer alır: "Gölge etme başka ihsan istemem". Derginin mukaddimesinde derginin ismine ilişkin olarak "(...) Diyojen hükemâ-yı Yunaniyyeden hum-nişinlikle şöhret-şiâr Sinoplu bir meczub-i kâmil olup meşreb ü mezhebi bu gazetenin muvâfik mesleği olduğundan bu isim ile tevsimi münasib görüldü (...) (Diyojen, 29 Şaban 1287) şeklinde bir ifade yer almaktadır. Bu ifade ile Terakki'nin Sinoplu Diyojen'e ilişkin mensubu olduğu felsefe okulu ve savunduğu hayat tarzına dair tanımlamaları bir anlamda kabul edilmekle birlikte (hum-nişinlik) onun sözünü sakınmama anlamında konuşma hürriyetine dayalı ahlak anlayışı sebebiyle dergiye isminin seçildiği belirtilmektedir. Türkçe nüshanın ilk sayısında doğrudan Terakki'ye bir cevap verilmek yerine Terakki'nin 3. sayısında yer alan bir şiirin eleştirisine yer verilir:

"Lûgat-ı Arabda bazı kere vav ile ye ilga-i kalp olunur imiş işittik. Lakin ayn harfinin ilga-i kalp olunduğunu işitmemiş idik. Hele bunu dahi Terakki efendinin düzdüğü şarkidan ögrrendik ol şair-i beliğ usfûr diyecek yerde asfûr demiş. Demek ki maarif çoğaldıkça kaide tevessü ediyor. Öyle ise biz de ol fazllin eserince gidelim ve düzdüğümüz nazirede zikr edeceğimiz zembûrek -za'sını -za'ya kalp edelim şarkl- saz muma-ileyh gafer Allahü bi-çare usfurun başına getirdiği beliyye-i mezkureye kanamayıp ayn'ından bozduğu elifi dahi medd-i sakîl ile çekmiş uzatmış yani elifin üzerine alamet-i medd-i vaz' edip usfûr resminde yazmış biz de gü-

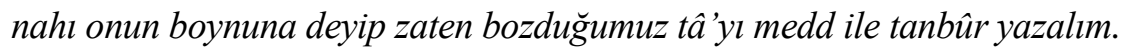
Şarki Yahut Garbi

Pek çok severçün tatllyı canım

Tanbûr-ı aşkım bağlar mekânım

A ̆gaç kovuğu dar-ül-amanım

Tanbûr-ı aşkım dağlar mekânım

Piş-i Rum'dur ba 'sub himmet

Mahsûl-ı tab 'im şehd letafet

Niş-i zabanım ağyara aft

Tanbûr-ı aşkım bağlar mekânım 
Kovan-ı nahle sürme elini

Köylü görürse kirar belini

Aşk arısı soksun dilini

Tanbûr-ı aşkım bağlar mekânım

Gencşen âsa etmem çırıldı

Hemcinsim ile kat'en dirildi

Ba ki korkmaz kavga hirıltı

Tanbûr-ı aşkım bağlar mekânım” (Diyojen, 29 Şaban 1287).

Bu metin ile Diyojen, Terakki'nin 25 Şaban 1287 (20 Kasım 1870) tarihli 3. sayısında yayınlanan "Asfûr aşkım dallar mekânım" nakaratlı şarkıyı hicvetmektedir. Metinde bahsedilen gramer yanlışı ise söz konusu şarkıda geçen nakarattaki "asfûr" kelimesi ile ilgilidir. Kelimenin aslı, "serçe" anlamına gelen "usfûr" kelimesidir ve ayn (ع) harfi ile yazılır. Ancak Terakki bu kelimeyi elif harfi (') ile yazmış ve ortaya "asfûr" kelimesi çıkmıştır. Temel bir gramer yanlışı üzerinden Diyojen'in Terakki'yi eleştirmesi ilk bakışta Terakki'nin daha önce Diyojen'e ilişkin kaleme aldığ1 yazılar düşünüldüğünde yeterli bir karşılık olarak gözükmemektedir. Buradan Diyojen'in Terakki'nin yazdıklarını önemsemediği gibi bir sonuca varılabilir. Ancak Diyojen'e ilişkin Terakki tarafından ortaya konulan "köpek", "köpek gibi yaşamak" ve dergi sahibi ile çalışanları hakkındaki “deli” tanımlamaları düşünüldügünde bunlar karşısında Diyojen'in kayıtsız kalması ihtimal dışı gözükmektedir. Bu bağlamda Diyojen'in metnini başka bir yaklaşımla ele almak gerekmektedir. Terakki, Diyojen ile ilgili olarak 25 Şaban 1287 (20 Kasım 1870) tarihli 3. sayısında yer alan mektupta "Şu kadar ki Türkçeyi henüz paralamaya başladiğımdan (...)” ibaresini kullanmıştır. Bu ibare ile Terakki, Diyojen'in yeni yayınlanacak Türkçe nüshasinı kast etmekle birlikte derginin sahibi Teodor Kasab'a da bir göndermede bulunmaktadır. Türkçe konuşan, ancak yazı yazamayan Kasab'ın yazılarına ve çevirilerine yeğeni avukat Lazaridis ile yakın dostu Fehmi'nin yardımcı olduğu dikkate alındığında (Kut 2011, 474) Diyojen'in Türkçe noktasında sıkıntılı bir dergi olacağı iması ortaya çıkmaktadır. Bu metin ile Diyojen rakibini kendi silahı ile vurmakta, dil noktasındaki maharetini rakibinin dil yanlışlarını ortaya koyarak kanıtlamaktadır. Bunun aynı zamanda gazetecilik mesleğinin temel enstrümanı olan "dil”'in kullanımı üzerinden "mesleki yetersizlik" iması da içerdiğini söylemek mümkündür.

Diyojen'in cevabından sonra Terakki, 5. sayısının büyük bir kısmını Diyojen ile ilgili yazılara ayırmıştır. Bu yazılardan ilki Diyojen'in 1. sayısında Phare du Bosphore gazetesini hedef alan “Gazetecilerin namusu yok mu?” başlıklı yazıya verdiği cevaptır. Diyojen, söz konusu yazıda Phare du Bosphore gazetesini başka gazetelerde yayınlanan haberleri kaynak göstermeden kullandığı için eleştirdiği yazıyı “(...) Terakki gibi daha dünyanın kaç bucak olduğunu bilmez yeni yetişmelere su-i misal mi olacaksın? Gözünü aç sonra elindeki fenere (Cümlede geçen "elindeki fener" kelime ile Phare du Bosphore gazetesinin ismine gönderme yapılmaktadır. Phare du Bosphore Türkçe'de “Boğaziçi Feneri” anlamına gelmektedir. Le Phare du Bosphore (1870-1890) İstanbul' da yayınlanan ve Patrikhane'nin çıkarlarını savunan bir gazetedir. İnuğur 2005, 171) kulak vermezler adeta çevirirler” (Diyojen, 29 Şaban 1287) şeklinde bitirmiştir. Bu yazıya Terakki, "Gazeteciler iş fena” başlıklı yazı ile karşılık verir:

"Herif zinciri koparmış. Ama kabahat yine bizde meşhur meseldir "deliye taş atma" derler. Diyojeni tımarhaneye tikmıslar bize ne. Diyojen kendi gibi daha iki muharrir tedarik edip Türkçe gazete çıkaracakmıs. Varsin çıkarsın andan ne hâsıl... Lakin orası bir şey değil herifin gidişine bakılır ise topumuza "hamamda deli var" dedirtecek bereket versin en evvel 
hamlesine yani birinci saldirlsina Phare du Bosphore tesadüf etmiş ve Courrier muharririni diline verd edip her satırinda namusuna dokunur derecede söz söylemiştir. Zan ederiz ki şarivari ötekinin berikinin hetk-i namusu için neşr edilir bir nüsha değildir (...)” (Terakki, 6 Ramazan 1287).

Terakki, bu durumla ilgili eleştirilerine "Diyojen'den bir fikradır ki cevabı kavs içinde verilmiştir” başlıklı ikinci bir yazı ile devam etmiştir:

"Gazetecilerin namusu yok mu (vardır, ama yüzü kasap süngeriyle silenler müstesna) Phare du Bosphore gazetelerden aldiğl bendleri hangi gazeteden aldı̆̆ını yazmayıp el malını babasının malı gibi neşr ettiğini anladık (acayip Diyojen birinci numarasında neşr ettiği (Amazon) alayı acaba kendi sermayesi mi idi?) gözünü aç. Sonra elindeki fenere kulak vermezler adeta çevirirler (edebini takın sonra hatra bakmayıp küpünü kırarlar)” (Terakki, 6 Ramazan 1287).

Diyojen'in ilk sayısında başka gazeteleri eleştirmesi Terakki tarafından "hetk-i namus"a dokunma olarak tanımlanmaktadır. Meslektaşlarına karşı Diyojen'in takındığı "rezil etme” üzerine kurulu tutum, Terakki tarafından hoş karşılanmamakla birlikte Diyojen' in diğer gazetelere getirdiği eleştiriler noktasında kendisinin de bunlara riayet etmemesi Terakki tarafından çok da "ahlaki" bulunmamaktadır. Bu duruma örnek olarak da Diyojen'in birinci sayısında yayınlanan "Ne güzel desise-i Harbiye ve Muhabbet-i Vataniyye” başlıklı yazıyı göstermektedir. Söz konusu yazıda Fransa'da kadınlardan oluşturulan ve "Amazon Alayl" ismi verilen birliklerden bahseden Diyojen, bu haber için kaynak göstermemiş sadece "gazetelerde gördük" ifadesini kullanmıştır. Burada dikkat çeken bir başka nokta ise "Diyojen'den bir fikradır ki cevabı kavs içinde verilmiştir" başlıklı yazıda kullanılan "fener" benzetmesidir. Diyojen'in Phare du Bosphore gazetesini eleştirirken gazetenin ismi üzerinden yaptığ "fener" benzetmesine Terakki, Sinoplu Diyojen'in gündüzleri elinde bir fener ile gezmesine gönderme yaparak cevap vermiştir.

Terakki'nin 5. sayısında yer alan bir diğer yazı ise "Varaka Diyojen'e saraka” başlığını taşır:

"(Varaka) Hani ĕglence olarak Fransızca ve Rumca çıkarılmakta olan Diyojen nam gazetenin haftada bir gün dahi Türkçe neşr edileceğini e ğlence nüshalarınızın birkaçında yazmış idiniz.

(Terakki) Öyle bir şey yazılmış idi.

(Varaka) Bak siz eğlence olarak yazdınız ama meğer sahih imiş herif geçen çarşamba günü birinci nüshasını çıkardı bilmem gördünüz mü.

(Terakki) Evet... Yazdı̆̆ı havadislerin hemen kâffesini gördük deyu nihayet veriyor. Bir gazete çıkmış idi o değil mi.

(Varaka) Tuhafi o değil. Siz her vakitte Diyojeni icale-i felâsifeden reis-i mezhep kelbi deyu yazardınız hatta bende onun için merak ettim de her gün Türkçe nüshası çıtı mı deyu sordurmakta idim. Çarşamba günü akşamı getirdiler bir de imzaya bakalım ki Diyojen Diyojen deyu dünyalara siğdıramadı̆̆ınız meğer şu bizim mahut eski Kasab Teodor imiş.

(Terakki) Imza ister kasab olsun ister ayvaz biz oralarda değiliz. Malum ya ayvaz 'kasab hep bir hesap' ikisi de indimizde musâvidir. Çünkü ayvaz olsa bundan daha iyisini yazacak değil idi ya. Isşte pek âla mukaddimesinde daha hikayeye başlamazdan evvel parsayı toplayacağını yazdiktan sonra Fransa ve Prusya muharebesi üzerine işbu muharebe ma'mure-i âlimi Ortaköy silahhanesine çevirdi deyu efkarına hitam 
vermiş ve bir de güzel kasab hikayesi yazıb ardı sıra birkaç ufak tekerleme ve bir şarkı ile meclisi tamam etmiştir. Ayvaz olsa ne nakil edecek idi ya Van'dan ya ormandan değil mi.

(Varaka) Sonradan Diyojen gazetenin ismi olduğunu anladım fakat şimdi de Diyojen ismini iş bu Kasab nereden aklina getirdi orası merak oldu.

(Terakki) A efendim bunda merak edecek ne var malum bir şey çünkü Teodor kasaplı̆̆ında dükkanın önüne yı̆̆ılan köpeklerin elinden aşırı yanmış sonra Diyojenin hükemâ-i kelbiyyeden olduğunu anlamış günde birkaç saat dükkanda oturmak için Diyojeni kira ile tutmuş. Hatta levhası bile bunların kasaplıklarında bir paskalya günü Kasab Teodor'un giyinip kuşanıp iki nefer çıră̆ı arkasında ciğer sırıklarıyla durduğunun ve nasılsa divane Diyojenin ayağı kayıp koyun kestikleri çukura düşerek amanın beni çıkarın deyu Teodor'a elini uzattı̆̆ının resmi bulunmuştur. Sonra bakmışlar ki olmayacak onlarda bazılarının hamallığı ekmekçiliği balıkçıllğg fesciliği ve daha emsalli sanatlarını terk edip gazeteciliğe başladıkları gibi bunlar dahi kasaplı̆̆ terk edip ve mezkûr hikayeyi levha için tecsim ettirip yanlarına ehl-i sanattan daha birkaç kişi ve her sazdan çalar bir şair uydurarak gazeteciliğe başlamışlar. Ne var kâr ayıp mı" (Terakki, 6 Ramazan 1287).

Terakki daha önceki sayılarında dile getirdiği Diyojen'in içeriğine ilişkin eleştirilerine bu yazı ile devam etmektedir. Ancak buradaki tek fark daha önce dergiye ismini veren Sinoplu Diyojen'in felsefesi ve hayat tarzı üzerinden ilerleyen eleştiri bu sefer derginin yayınlanmış birinci sayısı üzerinden yani somut bir veri üzerinden ilerlemektedir. Diyojen’in Türkçe nüshasının ilk sayısının yayınlanmasından sonra Terakki'ye göre Diyojen oldukça acemice ve yetersiz bir içeriğe sahiptir. Bu acemilik ve yetersizliğin sebebi ise derginin sahibi Teodor Kasab'tır. Terakki, Teodor Kasab'ın ismini “Kasab Teodor” şeklinde zikrederek asıl mesleğini "kasap” olarak tanımlamaktadır: "Imza ister kasab olsun ister ayvaz biz oralarda değiliz. Malum ya "ayvaz kasab hep bir hesap" ikisi de indimizde musavidir. Çünkü ayvaz olsa bundan daha iyisini yazacak değil idi ya". Bu kasap tanımlaması Diyojen'in serlevhasına ilişkin aktarılan hikayede de vurgulanmıştır. Kayseri'nin ünlü kumaşçılarından Kasapoğulları ailesine mensup (Kut 2011, 473) Teodor Kasab'ın kasaplık mesleğine ilişsin hiçbir deneyiminin bulunmaması düşünüldügünde bu tanımlamanın tahkir amacıyla yapıldığını söylemek mümkündür. Yazının son cümlesi ise bir diğer tahkir unsurunu işaret etmektedir: "Ne var kâr ayıp mı". Bu cümle ile Terakki, Teodor Kasab'ı kâr amacıyla gazetecilik mesleğine girmiş birisi olarak tanımlamaktadır. Bu tanımlamaların Diyojen tarafından birinci sayıda "Gazetecilerin namusu yok mu?" başlıklı yazıda Terakki için sarf edilen "yeniyetme" tabirine bir anlamda cevap olduğu söylenebilir.

Terakki'nin 5. sayısında yer alan yazılara Diyojen 4. sayısında kısaca değinir. Phare $d u$ Bosphore gazetesi hakkında 1. sayısında yazdıklarına gazetenin verdiği tepkiyi eleştiren Diyojen, Phare du Bosphore gazetesini savunan Terakki için “(...) birinci numaramıza taş atmaya cüret eden bazı Türk gazetesi mâhud gazeteyi tesâhube kalkışmıştı. Şimdi muhamisinin işgüzarlığını görsün de iftihar etsin" (Diyojen, 20 Ramazan 1287) ifadelerini kullanmıştır. Bu yazı sonrası iki dergi arasında yaşanan polemikte Phare du Bosphore gazetesi tekrar gündeme gelmez. Phare du Bosphore gazetesinin tekrar gündeme gelmemesi bir anlamda Diyojen'in bu gazeteye ilişkin yabancı taklitçiliği (bk. Diyojen, 18 Zilkade 1287) yaptı̆̆ 1 ve vatana hiçbir hizmette bulunmadığı eleştirilerine Terakki'nin de katıldığı şeklinde okunabilir. Başka bir yaklaşımla Terakki'nin Phare du Bosphore gazetesini savunmaktan çok Diyojen'e meslek ahlakı üzerinden yüklenmek 
için söz konusu gazeteyi kullandığı söylenebilir.

$\mathrm{Bu}$ durumun göstergesi ise Terakki'nin 5. sayısında yayınlanan "Diyojen'den bir fikradir ki cevabı kavs içinde verilmiştir" başlıklı yazıda yer alan "(...) Phare du Bosphore gazetelerden aldı $\breve{g}$ bendleri hangi gazeteden aldı̆̆ını yazmayıp el malını babasınin malı gibi neşr ettiğini anladık (...)" ifadesidir.

Diyojen dergisi, 20 Ramazan 1287 (14 Aralık 1870) tarihli 4. sayısında yayınlanan "Ehl-i meraka bir güzel hesap" başlıklı yazısında dönemin İran Şahı'nın Bağdat'a yapmış olduğu se-

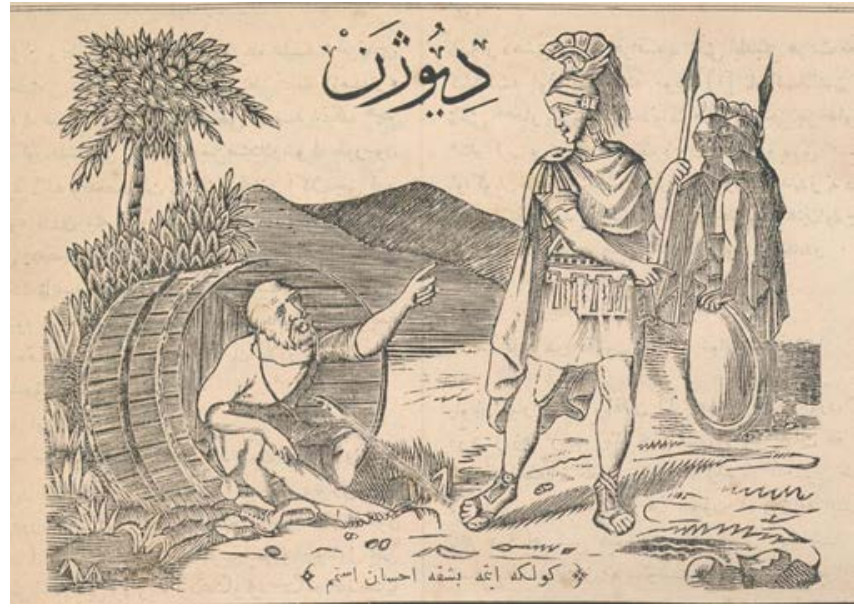

Fig. 1. Diyojen Dergisi Serlevhas1 yahati eleştirdiği için 50 gün kapatma cezası alır. Diyojen'in aldığı bu kapatma cezası sebebiyle Terakki ile Diyojen arasındaki kalem kavgası yaklaşık iki ay kesintiye uğrar. 13 Zilkade 1287 (4 Şubat 1871) tarihinde 5. sayısını yayınlayarak 50 günlük kapatma cezasını tamamlayan Diyojen, aldığı cezaya ilişkin birinci sayfasında "Heva-yi hasbihal veyahud görünmez kaza kefareti" başlıklı bir yazı yayınlar. Teodor Kasab, söz konusu yazıda Terakki’yi de unutmaz:

“(...) Âlem-i zû-fünun dedim de Terakki Efendi hatırıma geldi. Bîçare şu bir buçuk ay zarfinda ne kadar bozulmuş! Az kaldı tanıyamayacaktım. Bense koyunun bulunmadiğ yerde keçiye abdurrahman çelebi derler itikadında idim. Vakı'a umumun fark nîk ü bedde olan terakkisi böyle bir zan-ı sakime mahall birakmazsa da yalnı ben değil kendi de benim gaybûbetimden istifade ümit eyler idi. Meğerse o da sayemde geçinen fukaradan imiş. Hatta bazı ehl-i dikkatin rivayetine bakllırsa öteden beri bana taklide çabaladığı için müddet-i gaybûbetimde ne yol tutacağını şaşırmış kalmış... Ne büyük iftira! Neresi bana benzer? Görenler Allah için söylesinler! (...) Hah! hah! hah! Aman Terakki efendinin şu dediklerime kâmil-i memnuniyetten ağzının suları aktığını zihnimde biliyorum. Hay mashara hay. Sen ikibin ylllık Diyojen'i Eyüb oyuncaklarından mahud firıldak gibi havaya tabiattyla dört tarafa dönerek sana benzer mi zan ettin? Koca şaşkın yağma yok!

Benim istikamet-i mesleğim amme ile beraber ulü'l-emr nazarında müberhen ve hüveydadır. Yoksa ale'l-ıtlak kirk bin nüfus-ı muhtelife hakkında ettiğim hesab-ı hevayenin her nasılsa üst yanındaki ibareye karışmış olmasından dolayı münteç olduğu ihtar-ı mücerred adet birini bulsun maksadına mebnî olduğunda iştibahın olmasın. Zira müddet-i ta'tilimin tenzil buyrulmasıyla mazhar-ı afv ve taltif oluşum senin gibi genç beyinler nazarında efkârımın istikametini ilan ve ispat içindir. Binâenaleyh şu lutf-ı celîl ki vatan-ı azizimizin hayrina hıdmet olan efkâr ve makasıd-ı seniyyeyi kendime bedreka ve pey-rev-i ittihaz etmiş olduğumun inzar-l kibar ü sigar da sidk u sübutunu müeyyeddir. Borçlu olduğum şükr ve mahmidetini istikamet-i insilakeme asla halel getirmeyerek ibraz hidamâtı müstahsene ile ifaya çalışacağımı ilan eder ve şu ta'til müddetimde 
müşterilerimi Terakki'ye tenezzül ettirdiğimden dolayı hâsıl olan teessür kalbimi tevveccühat-ı sabıkalarının merkez-i aslîsine ric'atiyle izâleye muvaffak olacağımı ümîd eylerim" (Diyojen, 13 Zilkade 1287).

Bu yazı ile Teodor Kasab, Terakki'nin 5. sayısında kendisine dair yaptığ “ "kasap" benzetmesine ve mesleki yeterliliğini sorgulamasına karşılık vermektedir. Teodor Kasab, gazeteci olarak izlediği yolu "vatan-ı azizimizin hayrına hıdmet" olarak tanımlamıştır. Bu yolu kendisine "kılavuz" edindiğini ve bunun da herkes tarafından bilindiğini belirtirken aldığı kapatma cezası sonrası tekrar yayınlanmasını da mesleğinde izlediği yolun doğruluğunun delili olarak göstermektedir. Bu yazı ile Diyojen önceki dört sayısında kaleme aldığı yazılardan farklı olarak ilk kez Terakki'yi doğrudan hedef almış ve Terakki tarafından kendisine ilişkin yapılmış tanımlamalara karşılık vermiştir. Aynı sayıda yer alan "Görünür kaza” başlıklı yazı ile de Terakki'nin içeriği konusunu gündeme getirmiştir:

"Mahmutpaşa caminin merdivenleri o derece aşınmış ki çamurlu ve kat-
larda inip çıkmak adeta hayatını tehlikeye koymaktır. Hala karlı hava-
larda Allah imdad eyleye. Gazeteler böyle şeyleri hükümet-i seniyyeye
ihtâr etmek lazım gelirken şimdiye kadar hiçbiri ve bi'l-husus hayli va-
kitler bu merdivenlerin öte tarafinda matbaası bulunmuş olan Terakki
Efendi ağzını bile açmadı. Lakin Terakki'nin sukutunda sebeb var. Onun
için bir şey demez. Çünkü bîçarenin eğlence nüshası o derece bıda'âdan
mahrum ki halkı güldürmek için ne renge gireceğini bilmiyor binae-
nâleyh "karlı havalarda ortalık buz tuttuğu vakit bu merdivenlerden
yuvarlanıp tuhaf bir kllığa girersem belki müşterilerimi güldürürüm.
Hazır yanı başımda böyle bir sermaye var iken niçin boşboğazlı ederek
elimden çıarayım” diye sukût ediyor. Allah muvaffak eylesin. Ne diye-
lim” (Diyojen, 13 Zilkade 1287).

İçerik noktasında Terakki'nin Teodor Kasab'ın ismi üzerinden yaptığı “kasap” benzetmesi karşısında Diyojen rakibini bilgiden yoksun olarak tanımlamıştır. Bu tanımlama ile Diyojen, Terakki'nin mizah noktasında "hiciv" yapmaktan ziyade kendisini “tuhaf” durumlara sokarak okuyucusunun karşısına çıktığını belirtmektedir.

Terakki'nin, Diyojen'in içeriği hakkında yaptığı "kasap" tanımlaması üzerine kurduğu serlevhaya ilişkin hikayesine Diyojen, 6. sayısında karşılık vermiştir:

"Bir zat tarafindan gönderilen varakadan hülâsa edilmişstir

Kiraathanede

- (Hizmetçiye) Bugün Terakki çıkmadı mı?

- Hayır efendim cuma olduğundan çıkmadı. Cuma günleri "şalvarı" çıkar.

- Getir bakalım

- (Bad'el-kıra'e yanında bulunan bir zâta) Canım efendim bu Terakki'nin şarivarisi hakkında bendenizin bir müşü̈lüm var.

- Nasil efendim?

- Bendenizin bildiği Avrupa'da çıkan bu makûle tuhaflık gazetelerinde serlevha olarak konulan resimlerin kafası bir maksada mebni imiş. Hatta burada basilan Diyojen'in bile resimleri nasıl manalı olduğu tarihşinasanın malumudur. Bu halde şu Terakki'nin serlevhasina konulan resimler niçin böyle değildir?

- Vakıa hakkınız var. Hatta onu bendenizde düşündüm. Hiçbir mana vere- 
medim idi. Muahharen öğrendim. Meğerse hepsinin manası varmış.

- Acaip! Ne imiş?

- Efendim bunlar matbaa halkı imiş. Hatta şu orta yerde duran sahib-i imtiyaz imiş.

- Zannetmem lehçesi andırlyor ama elbisesi hiç benzemiyor.

- Çünkü bu bizim bildiğimiz elbisesi değil. Viziteye gittiği vakit "sivil" urbası imiş. Lakin aceleye mi gelmiş nasıl olmuş bilmem fesini değiş̧tirmeyi unutmuş.

- Hatta dikkat buyuruyor musunuz? Azıcık başını eyse takmış olduğu diplomat yakalı̆̆ burnuna girecek.

- Sahi öyle! Hiç dikkat etmedimdi.

- Lakin her ne ise hakkâk pek usta şey imiş aşk olsun fotoğrafyadan hiç farkı yok.

- Vakıa öyle! Acaba kime yaptırmıslar?

- Yaptırdıkları adamdan hiç me'mul olmaz. Postahane yanında 20 paraya mühür kazan Buharalı imiş.

- Acaip!

- Evet ibtida resimlerini heyetce fotoğrafya ile aldırmışlar sonra o resmi hakkâka vermişler ise de bu resimden pek iyi hak olunamayacağını beyan etmesi üzerine takımca gelip beher gün dört saat kadar karşısında durarak güç hal ile bir levha kazdırmışlar.

- Canım efendim taciz ettik ama afv edersiniz ötekiler kim imiş?

- Sol tarafta frenge tokat vuran matbaanin memur-l kalemiyyesinden biri ve Frenkte Fransizca hevacesi imiş.

- Söylemek işime el vermez. Onları da siz bulunuz bu kadar meraktan kurtuldunuz ya.

- Rica ederim efendim onları da tarif buyursaniz.

- Vallahi efendim ben bu muhavereyi Diyojen'e göndermek efkârındayım.

$O$ adam ise daha ahretten yeni geldi. Kendisine sual edelim ĕger bir daha azimete niyeti varsa onları da söylerim.

- Hiç niyetim yok yahut zahmet buyurmasaniz.

(Diyojen)" (Diyojen, 18 Zilkade 1287).

Diyojen'in serlevhasında yer alan Sinoplu Diyojen ile Büyük İskender arasında yaşanan meşhur sahneyi paskalya günü koyun kesen Diyojen'in düştüğü kuyudan çıkarmak için Teodor Kasab'ın elini uzatması şeklinde tasvir eden Terakki' ye cevap olarak yazılmış bu metinde Diyojen'in temel hareket noktasını Terakki Eğlencesi'nin (“Terakki Eğlencesi”, Terakki'den farklı bir dergi olmayıp Terakki'nin cuma günleri yayınlanan nüshasının ismidir. 23 Ramazan 1287 (17 Aralık 1870) tarihinde Salı ve Cuma günleri yayınlanan Terakki'nin Cuma nüshasının ismi "Terakki Eğlencesi" olmuş ve sıra numarası da "1"den başlamıştır (ayrıca bk. Demirkol 2016, 141-160)) serlevhasının "manasız"lı̆̆ı oluşturmaktadır. Avrupa'da yayınlanan mizah dergilerinin serlevhalarının belirli bir amaca hizmet ettiğini belirterek hareket noktasını bir anlamda meşrulaştıran Diyojen, kendi serlevhasını da bu noktada örnek olarak göstermektedir. Kendi serlevhasının tarihi bir olayı anlatması, serlevhada yer alan kişilerin de tarihi birer şahsiyet olmaları ve bu şahsiyetlerden Diyojen'in hayat felsefesinin derginin işlevi ile uyumlu olması Diyojen dergisi için Avrupa'daki mizah dergilerine bakarak derginin misyonunu okuyucuya doğru anlatmaktadır. Terakki Eğlencesi'nin serlevhasındaki kişileri “matbaa halkı" olarak aktaran Diyojen, resmin ortasındaki kişinin derginin imtiyaz sahibi olduğunu belirtir. Terakki ve 
Terakki Eğlencesi'nin nüshalarında imtiyaz sahibi olarak Ali Raşid ismi yer almasına karşın imtiyaz konusunda Ali Raşid ile birlikte Filip Efendi'nin de adı geçmektedir (Ebuzziya Tevfik, Terakki gazetesinin “iltizam sahibi” olarak sadece Filip Efendi'nin adını zikretmektedir (Tevfik 1290, 79). Ancak Münir Süleyman Çapanoğlu gazetenin ilk sahibinin Ali Raşid olduğunu belirtmektedir: “(Terakki)'nin ilk sahibi Ali Raşit isminde bir Türktür. Filip Efendi gazetede ortaktı” (ayrca bk. Çapanoğlu 1962, 61)). Burada imtiyaz sahibi olarak Ali Raşid'den mi yoksa Filip Efendi'den mi bahsedildiği belirsizdir. Ancak metinde geçen "Viziteye gittiği vakit "sivil" urbası imiş" ifadesi ile tanımlanan imtiyaz sahibinin Ali Raşid olma ihtimali yüksektir. Ali Raşid hakkında Türk Basın Tarihi'nde yeterli bilginin olmayışı -hatta pek çok akademik çalışmada ismi yanlış tercüme sonucu "Ali Reşat" şeklinde geçmektedir- konunun açıklığa kavuşmasını engellemektedir. Bununla birlikte "frenge tokat atan" matbaa memuru olarak kimden bahsedildiği de meçhuldür. Terakki gazetesi çalışanlarının (Karaman, Terakki gazetesinin çalışanlarını Kemalpaşazade Sait (Lastik Said), Suphipaşazade Ayetullah, Ebüzziya Tevfik, İsmail Efendi, Hayreddin (Leh asıllı Karski) olarak belirttir (ayrıca bk. Kahraman 2011, 481)). Terakki ve Terakki Ĕglencesi dergisine ne kadar katkıda bulunduklarının tespiti, dergide yer alan yazıların imzasız olmasından dolayı imkansız olmakla birlikte derginin bir yazar künyesi olmaması da metinde geçen matbaa memurunun kim olduğu sorusuna cevap bulmayı güçleştirmektedir. Bu yazıda dikkat çekici bir diğer nokta ise serlevhayı yapan çizer ile ilgili bölümdür. Terakki Eğlencesi'nin serlevhasının altında çizer olarak "Manukyan" imzası bulunmaktadır. Kendisi hakkında literatürde hiçbir bilgi bulunmadığ 1 için neden Diyojen tarafindan "Yaptırdıkları adamdan hiç memül olmaz. Postahane yanında 20 paraya mühür kazan Buharalı imiş” şeklinde aktarıldığı da kafalarda soru işareti bırakmaktadır.

Diyojen, Terakki'nin içeriğine ilişkin eleştirilerine 7. sayısında "Artık ölülere rahmet okumamalı" başlıklı yazı ile devam eder. Yazı daha önce yayınlanan ancak kapanmış Sıhhatnüma isimli gazetenin tekrar yayınlanmaya başlayacağını konu edinmektedir:

"Vaktiyle "Slhhatnüma" isminde bir gazete neşr olunurdu. Hatırınıza geldi mi? Bu gazete evvel vakit her nasilsa muammer olamaytp vefat eylediği halde sahib-i imtiyazı yani "Terakki" ve "Terakki Ĕglence" ve müteveffâ "Terakki Muhadderat" ve'l-hâsıl Terakki'ye müteâllik kâffe-i edevât ve hırdavat sahibi bulunan zat-l mezkûr gazeteye bu kere yeniden bahş- $\iota$ hayat etmek tasavvurunda imiş. Pek âlâ eder. (...) "Terakki Ĕ̆lence" okumak bilir tulumbacılarla Türkçe ögrenmeye heves etmiş Vanlı ayvazlarl gereği gibi dil-sîr-i nimet-i medeniyyet etti. Inşallah'ül-rahman "Sihhatnüma" ile dahi harabe-i mülk-i irfan olan dar-ı şifa mamur ve abadan olur.

Lakin ne kadar müşteri tutabilecek? Orasını merak ediyorum. Çünkü tuhaflk gazetesinden üç yüz nüsha kadar satabiliyormuş diye işittim ki Istanbul'da okumak bilur tulumbacı ile ayvaz o nisbette imiş demek olur. Binâenaleyh ne kadar deli varmış orasını da öğrenmek isterim.

Herhalde mevcut gazetelerin en çok müşterilisi olacă̆ından şüphem yok" (Diyojen, 25 Zilkade 1287). 
İçerik noktasında bu yazı ile Diyojen, rakibini okuyucu kitlesi üzerinden eleştirir ve Terakki'nin okuyucu kitlesini "okumak bilir tulumbacılarla Türkçe ögrenmeye heves etmiş Vanlı ayvazlar" şeklinde tanımlar. Bir mizah dergisi olarak sahip olduğu içerik ile ancak düşük toplumsal statüye sahip bu okuyucu kitlesinin beklentilerini karş1laya(bile)n Terakki'nin 300 nüsha satmas1 da Diyojen'e göre bu durumun en önemli kanitıdır. Diyojen'in gerek Fransizca ve Rumca gerekse de Türkçe nüshasının tirajına ilişkin net bir rakamın bulunmaması (Hikmet Feridun Es, Diyojen'in 1 kuruşluk

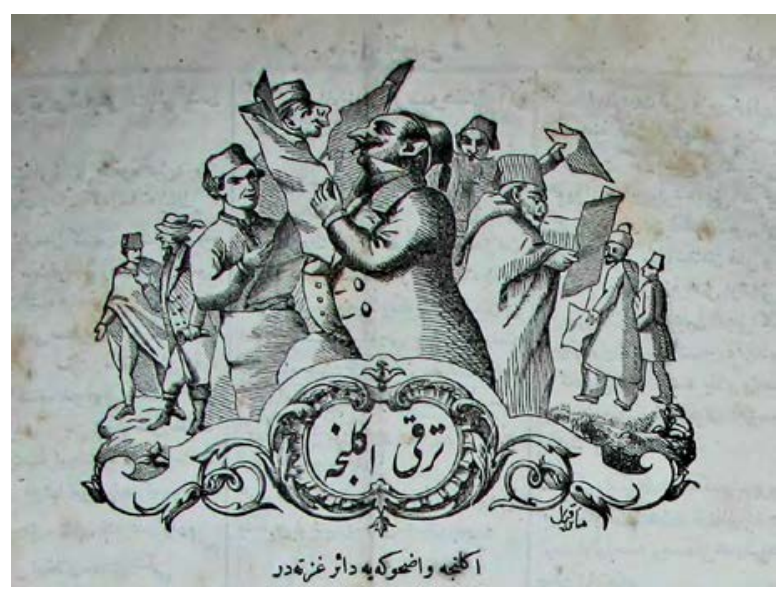

Fig. 2. Terakki Eğlencesi Serlevhası yüksek satış fiyatına karşın ilk nüshasının iki defa basıldığını belirtir ancak kaç adet basıldığına ilişkin bir bilgi vermez (ayrıca bk. Es, 17 Haziran 1945)) 300 rakamının dönem için düşük bir rakam olup olmadığına ilişkin net bir yargıya ulaşmayı engellemektedir. Diyojen tarafından istihzalı bir şekilde telaffuz edilen bu rakam dönem dergilerine ilişkin literatürde yer alan tek rakam olması açısından önemlidir. Söz konusu metin, daha önce polemik çerçevesinde gündeme gelen Terakki'nin imtiyaz sahibi konusuna da kısmen açılık getirmektedir. Metinde geçen Terakki Eğlence ve Terakki Muhadderat gazetelerinde imza olarak Ali Raşid ismi yer almakla birlikte "1288 senesi muharreminin dördüncü Pazar günü (ayrıca bk. Sihhatnüma, Sayı: 1, Hakkı Tarı Us Koleksiyonu no: 0291)” yayınlanmaya başlayan Sihhatnüma gazetesinde de Ali Raşid imzası bulunması Diyojen'in imtiyaz sahibi olarak hedef aldığı ismin Ali Raşid olduğunu gösterir.

Diyojen 8. sayısında yine Terakki'nin içeriğine ilişkin bir yazı yayınlar. Okuyucu mektubu olduğu belirtilen yazı 27 Zilkade 1287 (18 Şubat 1871) tarihli 10 numaralı nüshanın içeriği üzerine kurulmuştur:

"Bir müddettir herkes sabıkan "Terakki Eğlence" velâ-hakkan “--------“ nam gazeteden o derece nefret ediyor ki beher gün itirazı mutazammin Diyojen idarehânesine varakalar yağdırlyorlar. Bunların kaffesini tab etmeğe Diyojen nüshası kifayet etmeyeceği misillü esnafdan bulunmamız dahi bir yandan kendisini himâyeye mecbur eyledikten bu babda ashâb-ı evrakın afvlarını rica ederiz.

Lakin bazıları da ol derece güzel yazılmıs ki tab'etmemek elden gelmiyor. İste bu kabilden iki kut'asını bervech-i âti derc eyledik. Doğrusu böyle etrafli ta'rize insafi varsa Terakki efendi de gücenmez belki tahsin eder.

Bir varakadir

- Terakki'nin bu haftaki eğlencesini gördünüz mü?

- Evet satıcıların ve dün sabahda bizim ayvazın elinde gördüm fakat alıp okumadim.

- Aman pek görülecek bir halde idi.

- Bendeniz bu gazetenin etvar u güftarında bir tuhaflık görmedikten başka revş ifadesinden pek sıkıldiğım için okumuyorum ... Yine neler yazmış. - Bu nüshada (oku da bak münasebet var m1?) mukaddimesiyle söze ağaz gazino ve meyhanelerin naminı tagyir ve oralarda cereyan eden ahvali 
hikaye ve tâbir ederken ara yere bir amazon alay resmi koyduktan sonra yine meyhane fikrasinda devam ve mevki'e münasip bir misal iradiyla hatm ü perhiz-i kelam etmiş.

Pek münsib vâkl'a_meyhanelerin------halinden de halka haber vermeli ya!

Daha başka...?

- Bunlardan sonra "Timarhânenin baş penceresinden tiryaki çarşısına doğru derinden derinden bir sada" diye bir bend daha yazmış fakat bunun me 'ali pek de zabt olunur surette olmamasiyla hatrimda kalmadl. Ayvazdaki nüshayl getirtip okusak olmaz mı?

- Niçin olmaz istediğiniz halde getirsinler. "Gazete getirilerek bend-i mezkûr kira 'at olundukta"

- Vâkı 'a tuhaf "bakır çalmış" ve "ben deniz geçtim" gibi mahut ortaoyunlarında işitilen mazmunlarda var ama yine adeta deli saçması değil mi?

- Ay ne öyle çıtı ya!!!

Öyle işte bu gazete ayvazları eğlendirmek için mahut ibâreyi kendine sername-i ittihaz ederek ă̆zına geleni yazacak demek olur.

- Hangi ibâreyi?

- "Oku da bak hiç münâsebet var mı?” ibâresi.

- Efendim bu ibâre gazeteye sername değil belki meyhaneler ahvaline dair olan bende ve ihtimal $k i$ bu nüshanın kâffe-i münderecatına mukaddime ittihâz olunmuş olmall. Baksanıza nereye yazmış.

- Pek âlâ bu gazetenin sernamesi yok. Resmin altındaki sername deliği açık duruyor.

- O delik şimdi açıldi. Yoksa içinde sername olarak "Terakki Eğlence" ibâresi var idi. Geçende her nasılsa bir küçük taş atan olduğu için içindekiler dışarıya dökülüp hâneyi boş biraktılar. Sûretâ ol hanenin hâmîleri makamindaki haşerat ki üst tarafina tasfir olunan pat burun ve kaba sakal ve fesli ve şapkalt ve kerrakeli bir alay heriflerin suretleridir daireyi himayeye kadir olamadilar.

- Acayib! Ay şimdi bu haneyi böyle açık mı tutacaklar?

- Me'mul etmem. Çünkü göz önünde öyle açık bir hâne çirkin duracă̆ından belki "Amazon" alayı gibi nâdir'ül-âsâr bir şey bulup doldururlar...” (Diyojen, 2 Zilhicce 1287).

Diyojen, rakibinin içeriği hakkında daha önce kaleme aldığ 1 yazılardaki tanımlamalarına bu yazıda da devam etmiştir. Ancak dikkat çeken nokta yazının son kısmında yer alan "sername deliği” hususudur. Bu yazıya konu olan 10 numaralı sayı isimsiz yayınlanmıştır. Yani serlevhada daha önce yer alan "Terakki Ĕglencesi" ibaresi bu sayıda yoktur. Bu sayı ile birlikte üç sayı daha isimsiz yayınlanan Terakki gazetesinin Cuma nüshası 10 Muharrem 1288 (1 Nisan 1871) tarihinde Letaif-i Asar ismini alır ve imtiyaz sahibi de Mehmet Tevfik (Çaylak Tevfik) olur. Bu süreç içerisinde gazetenin Salı nüshası ise Terakki ismiyle yayınlanmaya devam eder ve 21 Muharrem 1288 (12 Nisan 1871) tarihinde o da ismini Letaif-i Asar olarak değiştirir. İmtiyazın el değiştirme sürecini Diyojen serlevhada yer alanların "matbaa halkı" olmasına gönderme yaparak "Geçende her nasılsa bir kü̧̈ük taş atan olduğu için içindekiler dışarıya dökülüp hâneyi boş bıraktılar” cümlesiyle aktarmaktadır. 
Diyojen'in 8. sayısında yer alan bir diğer yazı ise iki dergi arasında yaşanan polemiğin sonunu getirmekle birlikte üslubun da sertleşmesine sebep olmuştur:

"Aferin Terakki işte bu sefer gözüme girdin öteden beri bana taklide çabalaya çabalaya bütün bütün tutacağın yolu şaşırmış iken hele bu Salı günü çıkan nüshanın bir fikrasinı olsun bana benzetmeye muvaffak olabildin. Doğrusu beşinci numaralı nüshadaki mekteb muhaveresini güzel taklit etmişsin. Tebrik ederim. İşte her vakit

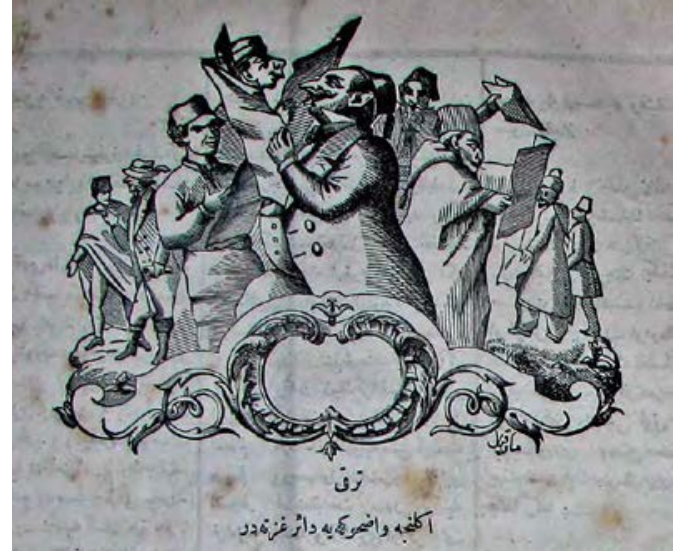

Fig. 3. İsimsiz Derginin Serlevhas1 bu yolda tab'a muvaffik şeyler yazmak fena mı olur? Şimdiye kadar senin yerinde başka biri olaydı çoktan bana benzerdi. Lâkin biraz zihnin kabadır da yazdı̆ğm şeylerin mezâyâsına birden bire varamazsin. Senin kusurun yalnı humk ve belahattır. Yoksa fena çocuk değilsin. Bu gabavet ise zeka gibi dâd-ı hakk olduğu için ayıp değildir. Bir şey ma'hazâ geç olsunda güç olmasin fevkince benim mukallid-i sahihim olmak sence vakite muhtaç ise dahi çabalayıp gabavetlikle me'yus olma. Zaman ile her şey kemâl olur. Derece derece böyle taklide muvaffik olduğunu gördükçe bendesini bütün bütün taht-l himayeme alıp ileri götürmeye ve ayvaz odalarından çıkarı kibar meclislerinde kendini bilir adamlarla bir sıraya çıkmana çabalarım (...)” (Diyojen, 2 Zilhicce 1287.)

Diyojen'in 5. sayısında "Mektepte" başlığı ile yayınlanan bir fikranın benzeri Terakki'nin 19. sayısında "Fransa'da bir Mektepte" başlığı ile yayınlanır. "Taklit" noktasından hareket eden Diyojen, rakibini “ahmaklık”, "kalınkafalılık” ve "bönlük" ile tanımlayarak üslubunu sertleştirmiştir. Bu üslup karşısında Terakki de Teodor Kasab'a ilişkin bir yazı yayınlar. Arşivlerde mevcut bulunan Terakki, Terakki Eğlencesi dergileri ile Terakki gazetesinin sayılarında rastlayamadı̆̆ımız bu yazının içeriğine ilişkin bilgileri Diyojen'in cevabından çıkarabilmekteyiz.

"Benim sana ettiğim letâiften şahsiyata mûte 'allik manalar çıkmadĭ̆ını anlatmak için ol emrde terbiyesizliğinle cehlinden bahs ederek seni biraz tahsil-i adab ve terbiyeye mecbûr eylemek lazım imiş. Bile[me]dim. Çünkü ben seni kadeten gazete ve gazeteci sıfatıyla tanırım. (Cenab-ı hakka bin kere hamd olsun) şahsen nasıl şey olduğunu bile bilmem ve bilmekte lazım değildir. Binaenaleyh "gazeteci elbette sanatını bilir" veyahut "sanatını bilmek lazımdır" itikadıyla sairleri gibi sana da bazı lâtife etmekte hiçbir be'is göremedim idi. Meğerse sen sanatın şöyle dursun hala terbiye-i zâtiyye ve şahsiyyât ne demek olduğunu anlayacak kadar iz'ân ve irfandan bile mahrum imişsin. Bilemedim.

Bi'l-farz şahsiyata girişilmek mecaz olsa bu cehaletle senin iltizam edeceğin kaide-i mübâhese iki nev'i den ibaret olabilir ki biri şütûm-i galize ve diğeri azv-i erâcîf ve iftiradır. Bu ise kendi hakkinda davet-i cezadır. Bence pek âladır. Doğrusu çok ahmak imişsin. Bilemedim.

Ama şimdi ögrendim. 
Binaenaleyh sana hâlisâne ihtar ederim ki ben Terakki'ye gazete ve (Ali Raşid)i gazeteci tanıdığım gibi sende Diyojen'i gazete ve (Teodor Kasab)ı gazeteci tanımaya mecbursun. (Teodor Kasab) müslümanmış hıristiyanmış Yahudi imiş veyahut evli imiş bekâr imiş na-bekâr imiş buralarına gerek aleni ve gerek zımnen girişmek senin haddin değildir. Nitekim (Ali Raşid) müslümanmış hıristiyanmış Yahudi imiş evli imiş bekâr imiş na-bekâr imiş buralarından bahs etmek caiz değildir. Ve âdetâ memnudur. Hilafi halinde adamın kuyruğunu tabe sapına çevirirler.

Lakin "Terakki gazetesi tulumbacılarla ayvazların gazetesidir. Yazdl $\breve{g} l$ şeylerin bir manası ve rabtı ve sebki yoktur. Bir fikr-i metin üzerine mübteni bir şey yazmaya muktedir değildir" demeye benim hakkım olduğu gibi seninde "Diyojen tatl sarf ediyor. Metin yazlyor. Yazdiğ şeylerde tariz edecek bir şey bulamıyorum. Onun için imanımızı gözeten nizâmı unutup da şahsiyata girişmek istemek gibi kahpelik ediyorum. Ah bir kere yakası elime geçse kendisinden ögrendiğim sözlerle etmeyeceğim tariz yoktur" demeye salahiyyetin vardir.

Isste bu dersi belle de ona göre hareket eyle. Edepsizlik ve tulumbactlıkla vazifenin haricine çıma. Diyojen böyle kendine ait olmayan şahsiyat nâmına müfteriyata cüretinden dolayı asla mesleğini değiștirmez. Her ne vakit şayan-ı istihza bir halini görsem yine tariz ederim. Hati 83 numaralı nüshanda gördüğ̈̈m bir bendi işte zirde derc eyledim. Aklını başına topla adam ol da hakkinda tariz ve istihzaya davet eyleme. İste bu kadar" (Diyojen, 9 Zilhicce 1287).

Anlaşılan o ki Terakki, Teodor Kasab'ın dini inancı üzerine bir yazı yayınlamıştır. Bu yazıyı şahsiyetine saldırı olarak tanımlayan Teodor Kasab, Terakki'yi “imanımızı gözeten nizam”a uymayarak "kahpelik" yapmakla itham etmektedir. Bu yazı ile Diyojen, Terakki ile arasında geçen polemiğe son vermiştir. Teodor Kasab'ın yazısına Terakki 21. sayısında karşı1lık verir:

“(...) Kasab Teodor ve sercemaat mezheb-i kelbi yani mahud Diyojen çelebi müştereken düzmüşs oldukları muharrer zât-ı âli ile üçü bir yere gelip simitçi sipası vari şarivari mesleğinde bir gazete çıkarmaya (...) ve hakkimızda dördüncü nüshasında bütün bütün ağzl kapandı (...) sermuharrerin isaet-i edebte maharati iş bu iki mazlum giriftara öyle bir tokat yedirdiği tamam bir buçuk ay ne kendilerine çene açmaya ve ne muharrer mahudda bezle ve yave saçmaya iktidar kaldı (...) Terakki hakkında (...) ăğına geleni söylemeye ve cevap sukut aldıkça ileri gitmeye başladiğından kendisine halisane bir ihtar dahi olundu muharrerin bu ihtara karşı değil böyle münâkaşa belki alnının damarı patladığından led'el-icâb müşatemeden bile ar ve hicab etmeyip cevap olsun her ne türlü olur ise olsun hemen arkasindan yetiştirilmesini bi'l-vâsıta matbaamıza tebliğe kanaat etmeyip (mahal...günah) olan kuyruğunu taba sapına çevireceğini söylemiştir (...)” (Terakki, Sayı:21, 15 Zilhicce 1287).

Terakki, Diyojen'e yanıtında onun kadar ağır bir üslup kullanmamış olmasına karşın Diyojen’i "simitçi sıpası" benzeri bir dergi, Teodor Kasab'1 da ar ve utanma duygusundan yoksun biri olarak tanımlamıştır. Rakibi için tanımladığı bu özellikler için de Diyojen'e 4. sayısında verilen 50 günlük kapatma cezasını kanıt olarak göstermiştir. Bu yazı ile Terakki'de Diyojen ile arasındaki polemiğe son noktayı koymuştur. 


\section{Sonuç}

Terakki ile Diyojen arasında yaşanan polemik yaklaşık bir yıl sürmüştür. Bu süreçte sadece Diyojen'in aldığı kapatma cezası süresinde polemik kesintiye uğramıştır. İki dergi arasında yaşanan polemik konularını; içerik, biçim ve mesleki konular olmak üzere üç başlıkta toplamak mümkündür. İçerik ile ilgili konuların ana hattı dergilerin birbirlerini mizahi açıdan yetersiz bulmaları şeklinde özetlenebilirken, biçime ilişkin konular daha çok dergi serlevhaları üzerinde yoğunlaşmaktadır. Mesleki konuların ana çatısını gazetecilik mesleği ve meslekte yeterlilik/ yetersizlik oluşturmaktadır. Genel olarak bu üç ana başlık altında toplanan polemik konuları polemiğin doğası gereği rakibin üzerinde iktidar kurma ya da rakibin eksikliğini gösterme noktasında söylemleri de şekillendirmiştir. Üzerinde yoğun olarak durulan içerik konusunda söylemin eksenini "eksiklik", "yetersizlik" ve "yoksunluk" tanımlaması oluşturmaktadır. Genel olarak her iki dergide birbirlerini mizah içeriğinden yoksun/yetersiz olma şeklinde tanımlarken Terakki bunu rakibinin ismi ve imtiyaz sahibi üzerinden dile getirir; "çırılçıplak bir fiçıda yaşayan meczup Diyojen ile kasapliktan gazeteciliğe geçen Teodor Kasab”. Diyojen ise rakibinin içeriğine ilişkin söylemini okuyucu kitlesi üzerinden kurgular; "okumabilir tulumbacılar ile Vanlı ayvazlar”. Her iki söylemin ortak paydası olan "eksiklik”, “yetersizlik” ve “yoksunluk" aynı zamanda polemik sürecinde her iki dergi içinde rakibi karşısında kendisini bir mizah dergisi olarak tanımlamanın yoludur. Aynı durum biçim konusunda da geçerlidir. Her iki dergi de birbirinin serlevhasını eleştirirken biçim ile içerik arasında bir bağlantı kurmayı ihmal etmemektedir. Bunun en somut örneğini ise Diyojen'in Avrupa'daki mizah dergilerinin serlevhaları ile içeriği arasındaki ilişkiyi göstererek Terakki serlevhasını "manasız" bulması oluşturmaktadır. Söylemin ve de üslubun en sert olduğu konu başlığı ise mesleki konulardır. Bu durumun altında yatan unsurun gazetecilik mesleğine yaklaşımları olduğu söylenebilir. Her iki dergide gazeteciliği ve varlık sebeplerini "millete ve devlete hizmet" düsturu çerçevesinde tanımlarken birbirlerini bu amaca hizmet etmemek ile itham etmektedirler. Gazetecilik anlayışları düşünüldüğünde bu itham en ağır suçlama olarak karşımıza çıkmaktadır.

Terakki ile Diyojen arasındaki polemik kronolojik olarak ele aldığında ortaya polemiğin asıl sebebinin "rekabet” ya da "iktidar kurma arzusu” olduğu görülmektedir. Daha önce de belirtildiği üzere polemiğin birinci evresine ilişkin Diyojen'in yazılarına ulaşılamıyor oluşu polemiğin başlangıç noktasını belirlemeyi imkansız hale getirmektedir. Bununla birlikte Diyojen'in Türkçe bir nüsha yayınlamaya başlayacağını ilan etmesi ile polemiğin filizlendiği göz önüne aldığında Türkçe mizah dergisi olarak yayın hayatını tek başına sürdüren Terakki'nin yeni rakibi karşısında sessiz kalmadığı, sahip olduğu iktidarı başka bir dergi ile paylaşmak istemediği anlaşlmaktadır.

Terakki ile Diyojen arasında yaşanan polemikte her ne kadar birbirlerinin eksikliklerini ve aksayan yönlerini gözler önüne serme eğilimi başat durumda ise de gazetecilik mesleğine dair yazılı olmayan kuralların varlığından söz etmek mümkündür. Anlaşılan odur ki "şahsiyete saldırmamak" bu yazılı olmayan kuralların başında gelmektedir. Dini inançlar, aile kurumu ve kişileri küçük düşürücü ifadeler "şahsiyet" noktasında değerlendirilmektedir. Yaşanan polemiğin sona ermesinde de bu kavramların gündeme gelmesi etkindir. Bu noktadan hareketle bugün "Basın Meslek Illkeleri" şeklinde formüle edilen etik kuralların 1870 yılında mizah dergiciliğinde geçerliliği olduğu ve de pratikte de var olduğu söylenebilir.

Ceride-i Havadis gazetesi ile Tercüman-ı Ahvâl gazetesi arasında yaşanan Türk Basın Tarihi'ndeki ilk polemik ile Terakki ve Diyojen arasında yaşanan polemiği aynı kıstaslar üzerinden değerlendirmek mümkündür. Her iki polemiğinde başlangıç noktasının mesleki rekabet ve iktidar kurma arzusu üzerinden şekillenmesi, iktidar tesis etmenin ilk adımı olarak içeriğin ön pla- 
na çıkarılması ve son aşamada Müslüman-Gayrimüslim gazete/dergi sahipliğinin gündeme gelmesi belirgin unsurlar olarak ortaya çıkmaktadır. Bu unsurlar üzerinden Türk Basını'nın ilk dönemlerinde polemik geleneğinin temel dinamiklerini formülleştirmek mümkündür.

\section{KAYNAKÇA}

Arslan A. (2010). İlkçağ Felsefe Tarihi 2. İstanbul 2010.

Cevizci A. (2014). İlkçağ Felsefesi. Ankara 2014.

Çapanoğlu M. S. (1962). Basın Tarihine Dair Bilgiler ve Hatıralar. İstanbul 1962.

Demir Ş. (2004). "Tartışma ve Polemik Kavramlarına Dair”. 21. Yüzyılda Eğitim ve Toplum Dergisi 3/9 (2004) 183-192.

Demirkol G. (2016). “Türkiye’nin İlk Türkçe Mizah Dergisi: Terakki”. Gazi Akademik Baklş 10/19 (2016) 141-160.

Diyojen. Hakkı Tarık Us Koleksiyonu Yer No: 100.

Es, H. F. (17 Haziran 1945). "Tanımadığımız Meşhurlar”. Akşam Gazetesi.

İnuğur M. N. (2005). Basin ve Yayın Tarihi. İstanbul 2005.

Kahraman, A. (2011). “Terakki”. DIA 40. İstanbul (2011) 481-482.

Kut T. (2011). “Teodor Kasab”. DIA 40. İstanbul (2011) 473-475.

Özyıldırım A. E. (2014). Astr. Ankara 2014.

Ruzname-i Ceride-i Havadis. Milli Kütüphane Yer No: 1956 SC 20.

Sihhatnüma. Hakk1 Tarık Us Koleksiyonu No: 0291.

Terakki. Hakkı Tarık Us Koleksiyonu Yer No: 360.

Tercüman-ı Ahval. Hakkı Tarık Us Koleksiyonu Yer No: 369.

Tevfik E. (1290). Salname-i Hadika. İstanbul 1290. 